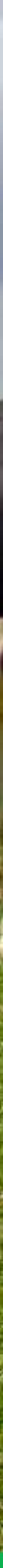

\title{
Effecten van derogatie op de kosten van mestafzet
}

Tanja de Koeijer, Harry Luesink en Pieter Willem Blokland

LE I

WAEENINGENUR 



\section{Effecten van derogatie op de kosten van mestafzet}

Tanja de Koeijer, Harry Luesink en Pieter Willem Blokland

Dit onderzoek is uitgevoerd door LEI Wageningen UR in opdracht van en gefinancierd door de Nederlandse Zuivel Organisatie NZO en LTO Nederland.

LEI Wageningen UR

Wageningen, maart 2016

NOTA

LEI 2016-024

LE I 
Koeijer, T.J. de, H.H. Luesink en P.W. Blokland, 2016. Effecten van derogatie op de kosten van mestafzet. Wageningen, LEI Wageningen UR (University \& Research centre), LEI Report 2016-024. 16 blz.; 0 fig.; 8 tab.; 10 ref.

De Nederlandse Zuivelorganisatie en LTO Nederland hebben LEI Wageningen UR gevraagd om de effecten van het eventueel wegvallen van de derogatie op de kosten van mestafzet en de benodigde mestverwerkingscapaciteit in beeld te brengen. Inzichten zijn verkregen via berekeningen met het LEI-mestmodel MAMBO, gebaseerd op het aantal bedrijven en dieren van het jaar 2013 en het mestbeleid van 2015. Gegeven de gehanteerde uitgangspunten, zoals voldoende beschikbaarheid van mestverwerkingscapaciteit, tonen de resultaten aan dat bij het wegvallen van de derogatie de totale mestafzetkosten voor de rundveehouderijsector met circa $116 \mathrm{mln}$. euro toenemen en die voor de varkenshouderij met $3 \mathrm{mln}$. euro afnemen. Voor de rundveehouderij komen daar circa $30 \mathrm{mln}$. euro aan kosten van extra stikstofkunstmest en $9 \mathrm{mln}$. euro aan kosten voor extra fosfaatkunstmest bij. In de akkerbouw nemen de kunstmestkosten met $3 \mathrm{mln}$. euro af.

De benodigde mestverwerkingscapaciteit zal bij het wegvallen van de derogatie met ruim $75 \%$ moeten toenemen tot circa $41 \mathrm{mln}$. $\mathrm{kg}$ fosfaat. Omdat de benodigde mestverwerkingscapaciteit op het moment van het eventueel verlies van derogatie mogelijk niet beschikbaar is, is ook nagegaan wat het effect van het wegvallen van derogatie op het extra mestaanbod op de mestmarkt is als deze wordt gecompenseerd door een vermindering van het aantal graasdieren. Op basis van de dieraantallen van 2013 is dan een reductie van $20 \%$ van het aantal graasdieren nodig.

Trefwoorden: derogatie, mestafzet, mestverwerking

Dit rapport is gratis te downloaden op http://dx.doi.org/10.18174/375204 of op www.wageningenUR.nl/lei (onder LEl publicaties).

(C) 2016 LEI Wageningen UR

Postbus 29703, 2502 LS Den Haag, T 07033583 30, E informatie.lei@wur.nl, www.wageningenUR.nl/lei. LEI is onderdeel van Wageningen UR (University \& Research centre).

\section{(cc) BY-NC}

LEI hanteert voor haar rapporten een Creative Commons Naamsvermelding 3.0 Nederland licentie.

(C) LEI, onderdeel van Stichting Dienst Landbouwkundig Onderzoek, 2016

De gebruiker mag het werk kopiëren, verspreiden en doorgeven en afgeleide werken maken. Materiaal van derden waarvan in het werk gebruik is gemaakt en waarop intellectuele eigendomsrechten berusten, mogen niet zonder voorafgaande toestemming van derden gebruikt worden. De gebruiker dient bij het werk de door de maker of de licentiegever aangegeven naam te vermelden, maar niet zodanig dat de indruk gewekt wordt dat zij daarmee instemmen met het werk van de gebruiker of het gebruik van het werk. De gebruiker mag het werk niet voor commerciële doeleinden gebruiken.

Het LEI aanvaardt geen aansprakelijkheid voor eventuele schade voortvloeiend uit het gebruik van de resultaten van dit onderzoek of de toepassing van de adviezen.

Het LEI is ISO 9001: 2008 gecertificeerd.

LEI 2016-024 | Projectcode 2282200169

Foto omslag: Fred van Welie 


\section{Inhoud}

1

Inleiding $\quad 5$

1.1 Aanleiding 5

1.2 Doel $\quad 5$

1.3 Afbakening $\quad 5$

2

$\begin{array}{ll}\text { Aanpak } & \mathbf{7}\end{array}$

$\begin{array}{lll}2.1 & \text { Methode } & 7\end{array}$

3

$\begin{array}{ll}\text { Resultaten } & 9\end{array}$

3.1 Mestafzetkosten $\quad 9$

3.1.1 Kosten bij mestafzetprijs 2013

3.1.2 Kosten bij mestafzetprijs 2015

3.1.3 Kosten bij mestafzetprijs 2015 inclusief overdracht VVO's 10

3.2 Kunstmestkosten 11

3.2.1 Stikstof 11

3.2.2 Fosfaat 11

$\begin{array}{lll}3.3 & \text { Benodigde mestverwerking } & 12\end{array}$

3.4 Compensatie derogatie-effect door vermindering aantal dieren 13

3.4.1 Benodigde reductie gegeven evenredige reductie graasdiersectoren $\quad 13$

3.4.2 Benodigde reductie gegeven reductie graasdiersectoren conform NEVscenario

4.1 Discussie

4.2 Conclusies 



\section{$1 \quad$ Inleiding}

\section{$1.1 \quad$ Aanleiding}

In het kader van de nitraatrichtlijn mag elke lidstaat van de Europese Unie maximaal $170 \mathrm{~kg} \mathrm{~N} / \mathrm{ha}$ uit dierlijke mest toedienen op gronden die aangewezen zijn als nitraatgevoelig. Nederland heeft derogatie gekregen voor graasdiermest voor bedrijven die aan de daarbij behorende voorwaarden voldoen. Sinds 2014 betekent dit dat bedrijven op zand- en lössgrond maximaal $230 \mathrm{~kg} \mathrm{~N} /$ ha uit graasdiermest mogen toedienen en op de overige gronden $250 \mathrm{~kg} \mathrm{~N} / \mathrm{ha}$. Daarbij moet minimaal 80\% van het areaal op deze bedrijven grasland zijn.

De toekenning van de derogatie is aan voorwaarden verbonden. Een van de voorwaarden is dat de Nederlandse fosfaatproductie niet boven het fosfaatplafond van $173 \mathrm{mln}$. kg fosfaat mag uitkomen. Het huidige Nitraat Actie Programma (NAP) loopt van 2014 tot 2018. In 2018 gaat het zesde NAP van start. Het is onzeker of ook in het zesde NAP weer derogatie zal zijn toegestaan. De onderhandelingen daarover gaan in 2016 van start. Indien in het zesde NAP geen derogatie wordt toegestaan, zal dit grote effecten hebben op de hoeveelheid mest die extra wordt aangeboden op de mestmarkt. Hierdoor zullen naar verwachting de kosten voor mestafzet en de omvang van de benodigde mestverwerking sterk toenemen.

Op verzoek van NZO (Nederlandse Zuivel Organisatie) en LTO Nederland heeft LEI Wageningen UR onderzoek gedaan naar de vraag wat het effect van het mogelijk wegvallen van de derogatie is op de kosten voor mestafzet in de afzonderlijke landbouwsectoren: melkveehouderij, pluimveehouderij, varkenshouderij en akkerbouw. Ook geeft de nota het effect op de benodigde omvang van de mestverwerking weer.

Als de huidige derogatie wegvalt of een mogelijke nieuwe derogatie in 2018 niet wordt verleend, is de beschikbare mestverwerkingscapaciteit mogelijk onvoldoende om het extra mestaanbod op de mestmarkt te verwerken. Eén van de mogelijke beleidsvarianten is dan om de effecten van het extra mestaanbod op de mestmarkt te compenseren door een beperking van het aantal dieren. Ook deze beleidsvariant wordt in de nota beschreven.

\subsection{Doel}

Het doel van de nota is het verschaffen van inzicht in de effecten van het eventueel wegvallen van de derogatie op:

1. de kosten van de mestafzet per mestsoort

2. de omvang van de benodigde mestverwerkingscapaciteit

3. de benodigde krimp van het aantal dieren om het effect van het wegvallen van derogatie te compenseren.

\subsection{Afbakening}

\section{Kosten en baten beperkt tot mest en kunstmest}

Bij de berekening van de kosten en baten van derogatie voor de melkveesector wordt de inkomstenderving door het verminderde aantal melkkoeien buiten beschouwing gelaten, omdat dit buiten de scope van het onderzoek valt en bovendien een aanvullende analyse vereist. 


\section{Compensatie derogatie beperkt tot melkveehouderij}

Voorts wordt de analyse van de benodigde vermindering van het aantal dieren om het effect van het wegvallen van derogatie te compenseren, beperkt tot een vermindering van de melkveestapel. Een analyse over de uitruil tussen enerzijds derogatie en anderzijds het 'niet overschrijden' van het fosfaatplafond is alleen voor de melkveehouderij relevant omdat de melkveehouderijsector het zelf opgelegde sectorplafond overschrijdt. Onder melkveehouderijsector wordt hierbij verstaan melkkoeien, kalfkoeien en bijbehorend jongvee (CBS-categorieën 100; 101 en 102). Een overschrijding van het fosfaatplafond geldt niet voor de andere veehouderijsectoren. 


\section{Aanpak}

\section{$2.1 \quad$ Methode}

\section{Varianten}

Om de effecten van het mogelijk wegvallen van derogatie te berekenen zijn twee varianten onderscheiden: 'Wel derogatie' en 'Geen derogatie'. Voor beide varianten zijn de mestafzetkosten, kunstmestkosten en de benodigde mestverwerking in beeld gebracht. Het verschil in mestafzetkosten, kunstmestkosten en benodigde mestverwerking tussen de variant 'Wel derogatie' en 'Geen derogatie' geeft het effect weer van het eventueel wegvallen van derogatie.

\section{Mestaanbod en plaatsingsruimte}

Voor het berekenen van de hoeveelheden mest die geproduceerd worden, de omvang van het mestaanbod en de plaatsingsruimte voor mest in de Nederlandse landbouw is gebruik gemaakt van de meest recente resultaten van een berekening met het LEI-mestmodel MAMBO. Deze modelversie is gebaseerd op het aantal bedrijven en dieren van het jaar $2013^{1}$ en het mestbeleid van 2015 (De Koeijer et al., 2015a). De resultaten zijn gebruikt voor de variant 'Wel derogatie'. Voor de variant 'Geen derogatie' is een aanvullende MAMBO-berekening gemaakt waarbij de enige verandering is dat de gebruiksnorm dierlijke mest voor alle gewassen en alle bedrijven maximaal $170 \mathrm{~kg} \mathrm{~N}$ per ha is.

\section{Mestafzetprijs en mestverwerking}

Voor het berekenen van de mestafzetkosten is niet alleen inzicht nodig in de hoeveelheid mest die van het bedrijf moet worden afgevoerd, maar ook in de afzetprijs. De afzetprijs is afhankelijk van het aanbod van mest en van de vraag naar mest. Vanwege het grotere aanbod van mest dan de vraag naar mest, kan de vraag naar mest vertaald worden naar de vraag naar afzetmogelijkheden. Hoe groter het aanbod van mest, hoe groter de vraag naar afzetmogelijkheden wordt. Hierdoor zal de prijs voor het afzetten van mest hoger worden. Op basis van de relatie tussen het aanbod van mest en de afzetmogelijkheden voor mest wordt de bijbehorende mestafzetprijs afgeleid. Hierbij wordt gebruik gemaakt van een eerder uitgevoerde analyse naar de relatie tussen vraag (afzetmogelijkheden) en aanbod van mest en de mestprijs (De Koeijer et al., 2013). Vervolgens zijn de kosten en baten van de mestafzet per sector berekend.

Voor de definitie van mestverwerking is de definitie conform de wetgeving gebruikt. Deze luidt (Bron: Tweede kamer, 2013 en 2014):

- export van onbewerkte en bewerkte mest

- verbranden van pluimveemest en

- verwerken van mest tot producten met meer dan 85\% droge stof (korrelen).

Aangenomen is dat bij de variant 'Geen derogatie' het extra aanbod op de mestmarkt verwerkt wordt door de mest te drogen en te korrelen. De plaatsingsruimte voor de export van onbewerkte en bewerkte mest in de nabijgelegen landbouwgebieden in het buitenland is namelijk grotendeels benut. Voor het afzetten van de mest in verder weg gelegen gebieden is het goedkoper om de mest eerst te drogen en te korrelen en vervolgens te exporteren. De poorttarieven voor het drogen en korrelen van mest bedragen 16-18 euro per ton (Twence, 2016, Ecoson, 2015, Verkerk, 2016). Met de transportkosten naar de fabriek van 2-4 euro per ton komt dat neer op een prijs af-boerderij van ongeveer 20 euro per ton.

${ }^{1}$ Sinds 2013 is de melkveestapel gegroeid en dus de mestproductie groter. Echter, voor het berekenen van het effect van het eventueel wegvallen van de derogatie maakt het gekozen basisjaar niet veel uit aangezien het gaat om het verschil tussen 'Wel' en 'Geen derogatie'. De hoeveelheid extra mest die door het verlies van derogatie op de markt komt, is bij het aantal dieren van 2013 niet anders dan bij het aantal dieren van 2015. 


\section{Kunstmestkosten}

Door het vervallen van derogatie mag er minder dierlijke mest worden aangewend. Hierdoor zal ter compensatie meer kunstmest worden aangewend. Daarom zijn ook de effecten op de kosten voor kunstmest in beeld gebracht. Aangenomen is dat de reductie van de hoeveelheid werkzame stikstof uit dierlijke mest in de variant 'Geen derogatie' wordt vervangen door stikstof uit kunstmest. Daarnaast is aangenomen dat nationaal gezien de aanwending van varkensmest zal worden vervangen door kunstmest aangezien de aanwending van varkensmest zal worden verdrongen door rundveemest. Dit komt doordat het goedkoper is om varkensmest te verwerken dan rundveemest (De Koeijer et al., 2015a). Bij de berekening van de extra kunstmestkosten is dan ook uitgegaan van de werkingscoëfficiënt van stikstof in varkensmest. Deze is circa 70\% (Haan, 2013).

\section{Veehouderijsectoren en gewasgroepen}

De berekende effecten voor de mestafzetkosten en de benodigde mestverwerkingscapaciteit worden in beeld gebracht voor mest van:

- rundvee

- varkens

- pluimvee en

- overige dieren. ${ }^{2}$

De kunstmestkosten worden onderscheiden per gewasgroep:

- grasland

- snijmais

- akker- en tuinbouwgewassen en

- gewassen op hobbybedrijven.

\section{Compensatie door krimp melkveestapel}

Voor het berekenen van de benodigde krimp van de melkveestapel als het effect van de derogatie op het extra mestoverschot wordt gecompenseerd door een vermindering van het aantal melkkoeien zijn twee subvarianten onderscheiden. Binnen de variant 'Geen derogatie' wordt de benodigde krimp van de melkveestapel berekend voor zowel een subvariant waarin $100 \%$ van het effect van derogatie op het extra aanbod van fosfaat uit mest van melkvee wordt gecompenseerd. De andere subvariant gaat uit van een compensatie van $50 \%$.

Het PBL en ECN (2015) verwachten in een scenarioanalyse van de ontwikkeling van de veestapels voor de Nederlandse Energie Verkenning (NEV15) dat bij een verhoging van de productiekosten de categorie 'overige graasdiersectoren' relatief meer krimpt dan de melkveehouderij. Daarom is ook voor dit scenario de benodigde reductie van het aantal graasdieren voor beide subvarianten van 100 en $50 \%$ compensatie doorgerekend.

\footnotetext{
2 Vleeskalveren, schapen, geiten, paarden, nertsen, eenden en konijnen.
} 


\section{Resultaten}

\subsection{Mestafzetkosten}

\subsubsection{Kosten bij mestafzetprijs 2013}

Bij een eventueel verlies van derogatie neemt het aanbod van rundveemest op de mestmarkt met 8 mln. ton toe (Tabel 3.1).

Doordat via VVO's (vervangende verwerkingsovereenkomsten) de te verwerken hoeveelheid rundveemest overgedragen wordt aan varkenshouders heeft het extra aanbod van rundveemest op de mestmarkt van $8 \mathrm{mln}$. ton tot gevolg dat er $5 \mathrm{mln}$. ton meer varkensmest verwerkt dient te worden. Door de extra kosten voor de afzet van rundveemest en de extra kosten voor mestverwerking voor varkensmest neemt de gemiddelde afzetprijs voor deze mestsoorten toe met 1,60 per ton.

De totale mestafzetkosten voor rundveemest worden meer dan verdubbeld in de variant 'Geen derogatie' en komen dan uit op bijna $150 \mathrm{mln}$. euro. De kosten voor de afzet van varkensmest stijgen met $14 \mathrm{mln}$. euro. Op basis van de mestafzetprijzen van 2013 bedragen in de variant 'Geen derogatie' de extra kosten voor de afzet van mest $95 \mathrm{mln}$. euro voor de veehouderijsectoren als geheel.

\section{Tabel 3.1}

De afzet van mest uitgedrukt in volume ( $\mathrm{mln}$. ton) en kosten ( $\mathrm{mln}$. euro) in 2015 op basis van de mestafzetprijs 2013 bij de varianten 'Wel' en 'Geen derogatie'

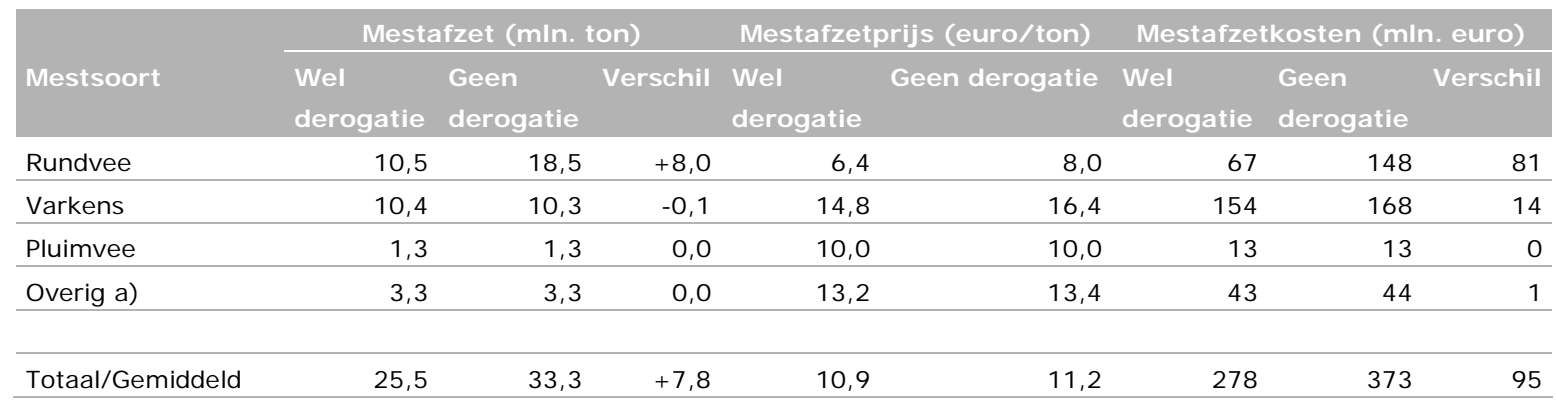

a) Vleeskalveren, schapen, geiten, paarden, nertsen, eenden en konijnen

Bron: MAMBO en Bedrijveninformatienet

\subsubsection{Kosten bij mestafzetprijs 2015}

Voor de berekening van de mestafzetkosten is als startpunt de in 2013 gerealiseerde mestafzetprijs genomen (Tabel 3.1) aangezien de berekeningen zijn uitgevoerd voor de situatie en bedrijfsstructuur van het jaar 2013 in combinatie met het mestbeleid van 2015.

In 2015 is de mestafzetprijs aanzienlijk hoger als gevolg van het toegenomen aanbod en de afgenomen vraag op de mestmarkt. Daarom zijn aanvullend ook de mestafzetkosten berekend op basis van de verwachte mestafzetprijzen voor het jaar 2015 (Koeijer et al., 2015b) (Tabel 3.2). ${ }^{3}$ Op basis van de mestafzetprijzen van 2015 bedragen in de variant 'Geen derogatie' de extra kosten voor de afzet van mest $114 \mathrm{mln}$. euro voor de totale veehouderijsector.

${ }^{3}$ De verwachting is dat deze prijs in de komende jaren weer zal dalen doordat de mestverwerkingscapaciteit als gevolg van het gestegen aanbod stijgt. 
Tabel 3.2

De afzet van mest uitgedrukt in volume ( 1.000 ton) en kosten ( $\mathrm{mln}$. euro) in 2015 op basis van de mestafzetprijs 2015 bij de varianten 'Wel' en 'Geen derogatie'

\begin{tabular}{|c|c|c|c|c|c|c|c|c|}
\hline \multirow[b]{2}{*}{ Mestsoort } & \multicolumn{3}{|c|}{ Mestafzet ( $\mathrm{m} / \mathrm{n}$. ton) } & \multicolumn{2}{|c|}{ Mestafzetprijs (euro/ ton) } & \multicolumn{3}{|c|}{ Mestafzetkosten ( $\mathrm{m}$ ln. euro) } \\
\hline & $\begin{array}{l}\text { Wel } \\
\text { derogatie }\end{array}$ & $\begin{array}{l}\text { Geen } \\
\text { derogatie }\end{array}$ & Verschil & $\begin{array}{l}\text { Wel } \\
\text { derogatie }\end{array}$ & Geen derogatie & $\begin{array}{l}\text { Wel } \\
\text { derogatie }\end{array}$ & $\begin{array}{l}\text { Geen } \\
\text { derogatie }\end{array}$ & Verschil \\
\hline Varkens & 10,4 & 10,3 & $-0,1$ & 18,0 & 19,0 & 188 & 195 & 7 \\
\hline Pluimvee & 1,3 & 1,3 & 0,0 & 17,0 & 17,0 & 23 & 23 & 0 \\
\hline Totaal/Gemiddeld & 25,5 & 33,3 & $+7,8$ & 14,6 & 14,6 & 374 & 488 & 114 \\
\hline
\end{tabular}

a) Vleeskalveren, schapen, geiten, paarden, nertsen, eenden en konijnen; b) Doordat het aantal dieren is gebaseerd op 2013 is dit een onderschatting van het werkelijke hoeveelheid doordat het aantal dieren in 2015 is toegenomen ten opzichte van 2013 Bron: MAMBO en Bedrijveninformatienet

\subsubsection{Kosten bij mestafzetprijs 2015 inclusief overdracht VVO's}

Bij de berekening van de mestafzetkosten per mestsoort (Tabel 3.1 en 3.2) is geen rekening gehouden met de bedragen die via de overdracht van de mestverwerkingsplicht via VVO's van de rundvee- naar de varkenshouderij plaatsvinden. Volgens De Koeijer et al. (2014) gaan rundveehouders voor de overdracht van de mestverwerkingsplicht ongeveer 3,50 Euro per $\mathrm{kg}_{\text {fosfaat }}{ }^{4}$ aan varkenshouders betalen. Bij een mestverwerkingsplicht van $75 \%$ in het zuidelijk overschotgebied, $50 \%$ in het oostelijk overschotgebied en $10 \%$ in overig Nederland dragen rundveehouders in de variant Geen derogatie ongeveer $32 \mathrm{mln}$. Euro over aan varkenshouders via af te sluiten VVO's. Voor de variant Wel derogatie wordt die overdracht via VVO's geschat op $22 \mathrm{mln}$. euro.

De totale kosten voor de rundveehouderijsector zijn bij de variant 'Geen derogatie' $116 \mathrm{mln}$. euro hoger dan bij de variant met derogatie. Voor de varkenshouderijsector zijn ze $3 \mathrm{mln}$. euro lager.

\section{Tabel 3.3}

De kosten (mln. euro) in 2015 inclusief de overdracht via VVO's voor de varianten 'Wel' en 'Geen derogatie' bij de mestafzetprijs van 2015

\begin{tabular}{|c|c|c|c|c|c|c|c|c|}
\hline \multirow[b]{2}{*}{ Mestsoort } & \multicolumn{3}{|c|}{ Mestafzetkosten ( $\mathrm{mln}$. euro) } & \multicolumn{2}{|c|}{$\begin{array}{l}\text { Kosten VVO's } \\
\text { (euro/ ton) }\end{array}$} & \multicolumn{3}{|c|}{ Mestafzetkosten (m/n. euro) } \\
\hline & $\begin{array}{l}\text { Wel } \\
\text { derogatie }\end{array}$ & $\begin{array}{l}\text { Geen } \\
\text { derogatie }\end{array}$ & verschil & $\begin{array}{l}\text { Wel } \\
\text { derogatie }\end{array}$ & $\begin{array}{l}\text { Geen } \\
\text { derogatie }\end{array}$ & $\begin{array}{l}\text { Wel } \\
\text { derogatie }\end{array}$ & $\begin{array}{l}\text { Geen } \\
\text { derogatie }\end{array}$ & verschil \\
\hline Rundvee & 116 & 222 & 106 & 22 & 32 & 138 & 254 & 116 \\
\hline Varkens & 188 & 195 & 7 & -22 & -32 & 166 & 163 & -3 \\
\hline Pluimvee & 23 & 23 & 0 & & & 23 & 23 & 0 \\
\hline Overig a) & 47 & 48 & 1 & & & 47 & 48 & 1 \\
\hline Totaal/Gemiddeld & 374 & 488 & 114 & 0 & 0 & 374 & 488 & 114 \\
\hline
\end{tabular}

a) Vleeskalveren, schapen, geiten, paarden, nertsen, eenden en konijnen Bron: MAMBO en Bedrijveninformatienet

\footnotetext{
4 Op dit moment bedraagt de prijs voor een VVO 1,50 euro per kg fosfaat maar de verwachting is dat deze prijs zal stijgen.
} 


\subsection{Kunstmestkosten}

\subsubsection{Stikstof}

Aangenomen is dat de hoeveelheid werkzame stikstof uit dierlijke mest die minder wordt aangewend als gevolg van het wegvallen van de derogatie, vervangen wordt door een vergelijkbare hoeveelheid stikstofkunstmest.

In de variant 'Wel derogatie' wordt $325 \mathrm{mln}$. kg stikstof uit dierlijke mest in de Nederlandse landbouw wordt afgezet. In de variant 'Geen derogatie' is die hoeveelheid $283 \mathrm{mln}$. $\mathrm{kg}$. Wanneer uitgegaan wordt van een gemiddelde werkingscoëfficiënt voor dierlijke mest van 70\%, dient er $29 \mathrm{mln}$. $\mathrm{kg}$ stikstof uit kunstmest extra aangevoerd te worden om dezelfde hoeveelheid werkzame stikstof aan te wenden. Bij een prijs van stikstofkunstmest van 1,04 euro per kg N (LEI-prijzenstatistiek) komt dat neer op extra kosten voor stikstofkunstmest van ruim $30 \mathrm{mln}$. euro (Tabel 3.4).

In de akker- en tuinbouw wordt er bij de variant 'Geen derogatie' meer rundveemest en minder varkensmest aangewend dan bij 'Wel derogatie'. Dit komt doordat er in de variant 'Geen derogatie' meer rundveemest op de mestmarkt wordt aangeboden. Door de toegenomen aanwending van rundveemest in plaats van varkensmest wordt er op akker- en tuinbouwgewassen in de variant 'Geen derogatie' meer stikstof uit dierlijke mest aangewend dan bij de variant 'Wel derogatie'. Dit komt doordat rundveemest een ruimere N/P-verhouding heeft (meer N dan P) dan varkensmest. Hierdoor gaat de akker- en tuinbouw er financieel iets op vooruit bij de variant 'Geen derogatie' (Tabel 3.4).

Tabel 3.4

Aanwending stikstof uit dierlijke mest en berekening van de kosten van aanvulling met kunstmest stikstof bij de varianten 'Wel' en 'Geen derogatie'

\begin{tabular}{|c|c|c|c|c|c|c|}
\hline \multirow[b]{2}{*}{ Gewas (groep) } & \multicolumn{2}{|c|}{$\begin{array}{l}\text { Aanwending stikstof } \\
\text { dierlijke mest ( } \mathrm{m} / \mathrm{n} . \mathrm{kg} \text { ) }\end{array}$} & & \multicolumn{3}{|c|}{ Kosten extra kunstmest } \\
\hline & $\begin{array}{l}\text { Wel } \\
\text { derogatie }\end{array}$ & $\begin{array}{l}\text { Geen } \\
\text { derogatie }\end{array}$ & Verschil & $\begin{array}{l}\text { Prijs } \\
\text { Kunstmest N } \\
\text { (euro/ kg) }\end{array}$ & $\begin{array}{l}\text { Werkings- } \\
\text { coëfficiënt }\end{array}$ & $\begin{array}{l}\text { J aarkosten extra } \\
\text { kunstmest ( } \mathrm{mln} \text {. } \\
\text { euro) }\end{array}$ \\
\hline Grasland & 211 & 166 & 44 & 1,04 & 0,7 & 32 \\
\hline $\begin{array}{l}\text { Akker- en } \\
\text { tuinbouwgewassen }\end{array}$ & 71 & 76 & -4 & 1,04 & 0,7 & -3 \\
\hline Hobbybedrijven & 8 & 6 & 1 & 1,04 & 0,7 & 1 \\
\hline Totaal & 326 & 283 & 42 & 1,04 & 0,7 & 31 \\
\hline
\end{tabular}

Bron: MAMBO en LEI-prijzenstatistiek

\subsubsection{Fosfaat}

De aanwending van fosfaat uit dierlijke mest daalt van $120 \mathrm{mln}$. $\mathrm{kg} \mathrm{P}_{2} \mathrm{O}_{5}$ bij de variant 'Wel derogatie' naar $102 \mathrm{mln}$. kg fosfaat bij de variant 'Geen derogatie'. Een groot deel (46\%) van de cultuurgrond in Nederland op derogatiebedrijven heeft de fosfaattoestand 'hoog'. Volgens de adviesbemestingen is er dan geen fosfaatbemesting nodig. Op 54\% van het areaal cultuurgrond met derogatie ( 907.000 ha) is de fosfaattoestand neutraal of laag. Op deze gronden dient de lagere fosfaatbemesting uit dierlijke mest aangevuld te worden met kunstmest om aan de adviesbemestingen te voldoen. Dat komt erop neer dat er $54 \%$ van $18 \mathrm{mln}$. $\mathrm{kg}$ is $9,7 \mathrm{mln}$. $\mathrm{kg}$ meer fosfaatkunstmest dient te worden aangewend om te bemesten volgens de adviesbemestingen. Bij een prijs van 0,88 euro per kg fosfaat (LEIprijzenstatistiek) komt dat neer op extra fosfaatkunstmestkosten van $9 \mathrm{mln}$. euro (Tabel 3.5). Op derogatiebedrijven met een neutrale of lage fosfaattoestand is $86 \%$ van de oppervlakte cultuurgrond grasland, $13 \%$ snijmais en $1 \%$ akker- en tuinbouw. De extra jaarkosten aan fosfaatkunstmest zullen dan ook naar verhouding over die gewassen zijn verdeeld. 
Tabel 3.5

Aanwending fosfaat uit dierlijke mest en berekening van de kosten van aanvulling met kunstmest fosfaat bij de varianten 'Wel' en 'Geen derogatie'

\begin{tabular}{|c|c|c|c|c|c|c|}
\hline \multirow[b]{2}{*}{ Gewas (groep) } & \multicolumn{2}{|c|}{$\begin{array}{l}\text { Aanwending fosfaat } \\
\text { dierlijke mest ( } \mathrm{mln} . \mathrm{kg} \text { ) }\end{array}$} & & \multicolumn{3}{|c|}{ Kosten extra kunstmest } \\
\hline & $\begin{array}{l}\text { Wel } \\
\text { derogatie }\end{array}$ & $\begin{array}{l}\text { Geen } \\
\text { derogatie }\end{array}$ & Verschil & $\begin{array}{l}\text { Prijs } \\
\text { kunstmest } \\
\mathrm{P}_{2} \mathrm{O}_{5} \\
\text { (Euro/ kg) }\end{array}$ & $\begin{array}{l}\% \text { areaal } \\
\text { fosfaattoestand } \\
\text { neutraal en } \\
\text { laag }\end{array}$ & $\begin{array}{l}\text { Jaarkosten } \\
\text { extra } \\
\text { kunstmest } \\
\text { ( } \mathrm{mln} \text {. euro) }\end{array}$ \\
\hline Snijmais & 13 & 11 & 2 & 0,88 & 54 & 1 \\
\hline $\begin{array}{l}\text { Akker- en } \\
\text { tuinbouwgewassen }\end{array}$ & 28 & 28 & 0 & 0,88 & 54 & 0 \\
\hline Hobbybedrijven & 3 & 3 & 0 & 0,88 & 54 & 0 \\
\hline
\end{tabular}

Bron: MAMBO en LEI-prijzenstatistiek

\subsection{Benodigde mestverwerking}

Voor het bepalen van de omvang van de benodigde mestverwerking is de gerealiseerde omvang van 2013 (17,2 mln. kg fosfaat; Van Bruggen, 2014) in het rekenmodel MAMBO gezet. Deze hoeveelheid was niet voldoende om alle mest af te zetten. Met MAMBO is berekend hoeveel mest er extra verwerkt dient te worden voor het creëren van evenwicht op de mestmarkt. MAMBO berekende ook welke mestsoort werd verwerkt op basis van de voorwaarde dat alle mest afgezet moet worden tegen de laagst mogelijke kosten.

In de variant 'Geen derogatie' dient er $58 \mathrm{mln}$. $\mathrm{kg}$ fosfaat uit dierlijke mest verwerkt te worden. Dat is $18 \mathrm{mln} . \mathrm{kg}$ fosfaat meer dan in de variant 'Wel derogatie' (Tabel 3.6). De $18 \mathrm{mln}$. $\mathrm{kg}$ fosfaat die extra verwerkt moet worden, komt overeen met ongeveer $5 \mathrm{mln}$. ton varkensdrijfmest. Tabel 3.6 geeft de hoeveelheid fosfaat weer die conform de wettelijke definitie van mestverwerking (paragraaf 2.1) wordt verwerkt. Ook geeft de tabel weer hoeveel daarvan rechtstreeks zonder verwerking in de vorm van verbranden, drogen en korrelen wordt geëxporteerd. Het verschil geeft aan hoeveel mestverwerkingscapaciteit voor het verbranden, drogen en korrelen van mest nodig is. De benodigde mestverwerkingscapaciteit is bij de variant 'Geen derogatie' $75 \%$ groter ten opzichte van de variant 'Wel derogatie'.

\section{Tabel 3.6}

De benodigde mestverwerking, de export van onbewerkte mest en de benodigde mestverwerkingscapaciteit uitgedrukt in $\mathrm{mln}$. $\mathrm{kg}$ fosfaat in 2015 voor de varianten Wel en Geen derogatie.

\begin{tabular}{|c|c|c|c|c|c|}
\hline \multirow[b]{2}{*}{ Mestsoort } & \multicolumn{2}{|c|}{$\begin{array}{l}\text { Mestverwerking } \\
\text { (mln. kg fosfaat) }\end{array}$} & \multirow[b]{2}{*}{$\begin{array}{l}\text { Waarvan } \\
\text { export a) }\end{array}$} & \multicolumn{2}{|c|}{$\begin{array}{l}\text { Mestverwerkingscapaciteit } \\
\text { ( } \mathrm{mln} . \mathrm{kg} \text { fosfaat) }\end{array}$} \\
\hline & Wel derogatie & Geen derogatie & & Wel derogatie & Geen derogatie \\
\hline Rundvee & 0,4 & 0,4 & 0,3 & 0,1 & 0,1 \\
\hline Varkens & 12,1 & 28,9 & 6,3 & 5,8 & 22,6 \\
\hline Overig & 2,3 & 3,4 & 1,3 & 1,0 & 2,1 \\
\hline Totaal & 40,3 & 58,2 & 17,0 & 23,3 & 41,2 \\
\hline
\end{tabular}

a) Export van onbewerkte mest en bewerkte mest bij zowel derogatie als geen derogatie Bron: MAMBO 


\subsection{Compensatie derogatie-effect door vermindering aantal dieren}

\subsubsection{Benodigde reductie gegeven evenredige reductie graasdiersectoren}

Door het wegvallen van de derogatie komt er $18 \mathrm{mln}$. $\mathrm{kg}$ extra fosfaat op de mestmarkt. Dit is vrijwel uitsluitend mest van graasdieren. In totaal wordt er $91 \mathrm{mln}$. $\mathrm{kg}$ graasdiermest geproduceerd (Tabel 3.7). Hiervan is $79 \mathrm{mln}$. kg van de melkveehouderij en $12 \mathrm{mln}$. $\mathrm{kg}$ van overige graasdieren. Om het effect van het wegvallen van de derogatie te compenseren is een vermindering van de fosfaatproductie door graasdieren van (18/91*100\%) $20 \%$ nodig. Dit betekent dat bij een compensatie van het derogatie-effect van respectievelijk 100 en $50 \%$, het aantal graasdieren op basis van de dieraantallen van 2013 met 20 en $10 \%$ moet verminderen.

\section{Tabel 3.7}

De benodigde reductie van het aantal graasdieren (\%) in 2015 met en zonder derogatie bij compensatie van 50 en $100 \%$ van het derogatie-effect bij aanname evenredige reductie van de graasdiersectoren

\begin{tabular}{|c|c|c|c|c|c|}
\hline & $\begin{array}{l}\text { Geen } \\
\text { compensatie }\end{array}$ & $50 \%$ compensatie & & $100 \%$ compensati & \\
\hline & $\begin{array}{l}\text { productie } \\
\text { ( } \mathrm{mln} . \mathrm{kg} \text { fosfaat) }\end{array}$ & $\begin{array}{l}\text { Reductie } \\
\text { ( } \mathrm{mln} . \mathrm{kg} \text { fosfaat) }\end{array}$ & Reductie (\%) & $\begin{array}{l}\text { productie } \\
\text { ( } \mathrm{mln} . \mathrm{kg} \text { fosfaat) }\end{array}$ & Reductie (\% ) \\
\hline Graasdieren & 91,1 & 9 & 10 & 18 & 20 \\
\hline Melkvee & 79,4 & 8 & 10 & 16 & 20 \\
\hline Overige graasdieren & 11,7 & 1 & 10 & 2 & 20 \\
\hline
\end{tabular}

Bron: MAMBO

\subsubsection{Benodigde reductie gegeven reductie graasdiersectoren conform NEV- scenario}

Een scenarioanalyse van de ontwikkeling van de veestapels voor de 'Nederlandse Energie Verkenning' (NEV15) (ECN en PBL, 2015) geeft aan dat bij een verhoging van de productiekosten, zoals een verhoging van de mestafzetkosten, de 'overige graasdiersectoren' relatief meer zullen krimpen dan de melkveehouderij. In de NEV15 is uitgegaan van een krimp van de 'overige graasdiersectoren' van $50 \%$. Daarom is aanvullend ook berekend wat dit betekent voor de resterend benodigde krimp van de melkveehouderij. In het geval van een meer dan evenredige krimp van de 'overige graasdiersectoren' zou de melkveehouderij op basis van de dieraantallen van 2013 bij een compensatie van het derogatie-effect van 100 en 50\% met respectievelijk 15 en $4 \%$ moeten krimpen (Tabel 3.8).

\section{Tabel 3.8}

De benodigde reductie van het aantal graasdieren (\%) in 2015 voor de varianten 'Wel' en 'Geen derogatie' bij compensatie van 50 en $100 \%$ van het derogatie-effect conform NEV15-scenario

\begin{tabular}{|c|c|c|c|c|c|}
\hline & $\begin{array}{l}\text { Geen } \\
\text { compensatie }\end{array}$ & $50 \%$ compensatie & & $100 \%$ compensat & \\
\hline & $\begin{array}{l}\text { productie } \\
\text { (mln. kg fosfaat) }\end{array}$ & $\begin{array}{l}\text { Reductie } \\
\text { (mln. kg fosfaat) }\end{array}$ & Reductie (\%) & $\begin{array}{l}\text { productie } \\
\text { ( } \mathrm{mln} . \mathrm{kg} \text { fosfaat) }\end{array}$ & Reductie (\%) \\
\hline Graasdieren & 91,1 & 9 & 10 & 18 & 20 \\
\hline Melkvee & 79,4 & 3,1 & 4 & 12,1 & 15 \\
\hline Overige graasdieren & 11,7 & 5,9 & 50 & 5,9 & 50 \\
\hline
\end{tabular}

Bron: MAMBO 


\section{$4 \quad$ Discussie en conclusies}

\subsection{Discussie}

Bij de berekening van de kosten en baten van derogatie voor de melkveesector is in de variant 'compensatie derogatie-effect door vermindering aantal dieren' de inkomstenderving door het verminderde aantal melkkoeien buiten beschouwing gelaten. Dit viel buiten de scope van het onderzoek. Het vereist bovendien een aanvullende analyse.

Te denken valt aan een eenvoudige berekening van de effecten voor een voorbeeldmelkveebedrijf; een analyse voor de melkveehouderijsector op basis van een berekening van de effecten voor een aantal representatieve bedrijven of een analyse van de effecten op de toegevoegde waarde per landbouwsector (zoals in Silvis et al., 2009 Tabel 7.5)

\subsection{Conclusies}

\section{De kosten van de mestafzet}

Gebaseerd op de prijzen voor mestafzet van 2015 stijgen, bij het wegvallen van de derogatie, de kosten van de mestafzet voor rundveemest met circa $116 \mathrm{mln}$. euro. De mestafzetkosten voor de overige mestsoorten is bij beide varianten vrijwel gelijk aan elkaar.

\section{De kosten voor kunstmest}

Door het wegvallen van de derogatie stijgen de kosten voor de rundveehouderij door de extra benodigde stikstofkunstmest met circa $30 \mathrm{mln}$. euro en voor fosfaatkunstmest met $9 \mathrm{mln}$. euro. In de akkerbouw dalen alleen de kunstmestkosten voor stikstof. De daling bedraagt $3 \mathrm{mln}$. euro.

\section{De omvang van de benodigde mestverwerkingscapaciteit}

Bij het wegvallen van de derogatie neemt de benodigde mestverwerkingscapaciteit met ruim $75 \%$ toe tot circa $41 \mathrm{mln}$. $\mathrm{kg}$ fosfaat.

\section{Compensatie door reductie aantal graasdieren}

Indien het effect van het wegvallen van derogatie op het extra mestaanbod op de mestmarkt wordt gecompenseerd door een vermindering van het aantal graasdieren, is op basis van de dieraantallen in 2013 een reductie van $20 \%$ nodig. Indien het aantal 'overige graasdieren' meer dan evenredig zou afnemen bedraagt de reductie van het aantal melkkoeien $15 \%$. 


\section{Literatuur}

ECN en PBL (2015). Nationale Energie Verkenning 2015, Energieonderzoek Centrum Nederland, Petten.

Kamerstukken II. 2012/2013. Wijziging van de meststoffenwet (invoering stelsel verantwoorde mestafzet). Tweede kamer der Staten Generaal, dossier 33322 kamerstuk nr. 14.

Haan, J.J., de en W. van Geel (2013). Adviesbasis voor de bemesting van akkerbouw- en vollegrondsgroentegewassen. Lelystad, PPO Wageningen UR.

Koeijer, T.J. de en H.H. Luesink (2015a). Effect $5^{\mathrm{e}}$ Nitraat Actie Programma op de bodembelasting, LEI-nota 2015-064, LEI Wageningen UR.

Koeijer, T.J. de, J. Buurma, H.H. Luesink en M. Ruijs (2015b). Beleid waterkwaliteit: kosten voor de landbouw; Een quick scan, LEI-nota 2015-147, LEI Wageningen UR.

De Koeijer, T. de, P.W. Blokland, J. Helming, H. Luesink en A. van den Ham (2014). Ex ante evaluatie wetsvoorstel Verantwoorde groei melkveehouderij, LEI-report 2014-019a, LEI Wageningen UR, Den Haag.

Koeijer, T.J. de, H.H. Luesink en G. Kruseman (2013). Effect van verplichte mestverwerking op de afzetprijs van mest; bijlage 9 in Willems et al. (2013), Ex ante evaluatie mestbeleid 2013, PBL, Bilthoven.

Twence (2016). 19 Euro voor verwerken kuub mest www.veeteelt.nl

Verkerk (2016). Interview over verwerking en export van mest. Nijkerk, Cumela, Persoonlijke mededeling.

Ecoson (2015). Ledenbijeenkomst nutrientenplatform bij Ecoferm te Uddel. Son, Ecoson, Persoonlijke mededeling. 
LEI Wageningen UR Postbus 29703

2502 LS Den Haag

T 0703358330

E publicatie.lei@wur.nl

www. wageningenUR.nl/lei

Nota

LEI 2016-024

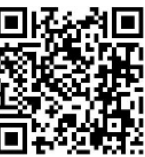

LEI Wageningen UR is een onafhankelijk, internationaal toonaangevend, sociaaleconomisch onderzoeksinstituut. De unieke data, modellen en kennis van het LEl bieden opdrachtgevers op vernieuwende wijze inzichten en integrale adviezen bij beleid en besluitvorming, en dragen uiteindelijk bij aan een duurzamere wereld. Het LEI maakt deel uit van Wageningen UR (University $\&$ Research centre). Daarbinnen vormt het samen met het Departement Maatschappijwetenschappen van Wageningen University en het Wageningen UR Centre for Development Innovation de Social Sciences Group.

De missie van Wageningen UR (University \& Research centre) is 'To explore the potential of nature to improve the quality of life'. Binnen Wageningen UR bundelen 9 gespecialiseerde onderzoeksinstituten van stichting DLO en Wageningen University hun krachten om bij te dragen aan de oplossing van belangrijke vragen in het domein van gezonde voeding en leefomgeving. Met ongeveer 30 vestigingen, 6.500 medewerkers en 10.000 studenten behoort Wageningen UR wereldwijd tot de aansprekende kennisinstellingen binnen haar domein. De integrale benadering van de vraagstukken en de samenwerking tussen verschillende disciplines vormen het hart van de unieke Wageningen aanpak. 

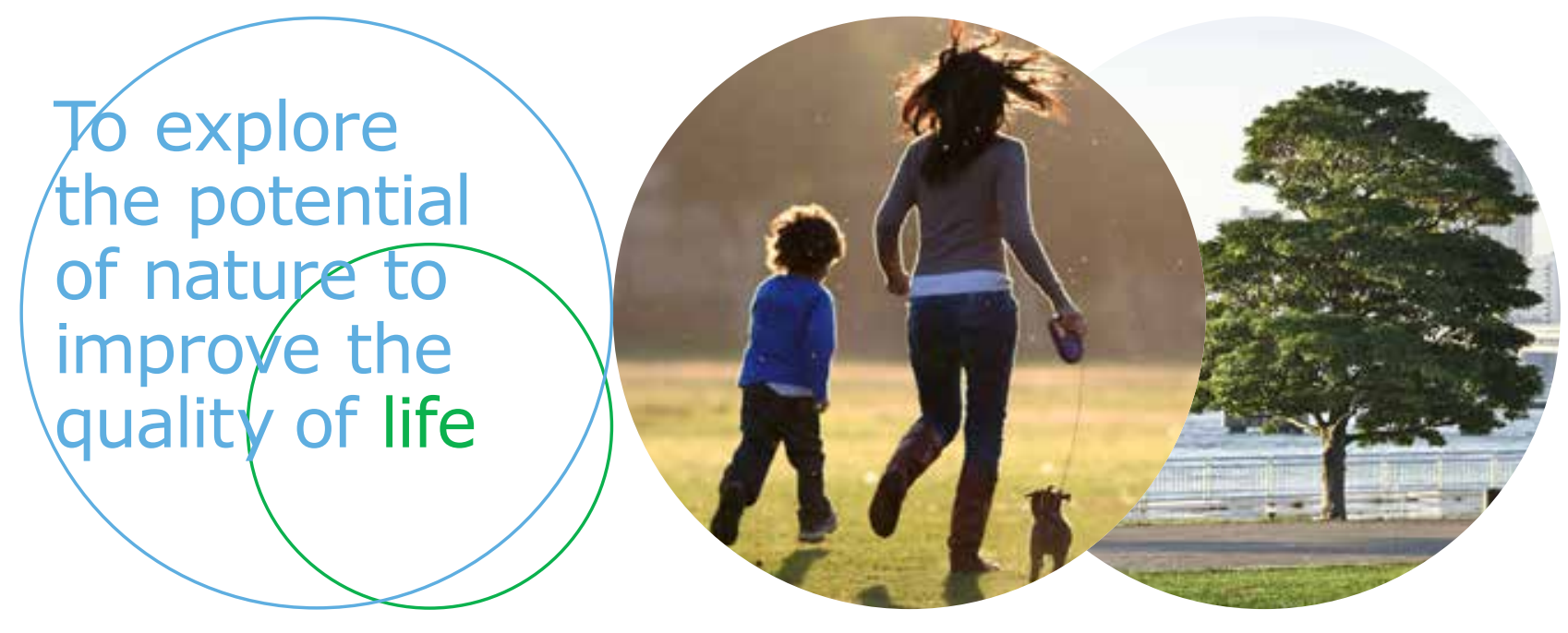

LEI Wageningen UR

Postbus 29703

2502 LS Den Haag

E publicatie.lei@wur.nl

www.wageningenUR.nl/lei

NOTA

LEI 2016-024
LEI Wageningen UR is een onafhankelijk, internationaal toonaangevend,

sociaaleconomisch onderzoeksinstituut. De unieke data, modellen en kennis van het LEI bieden opdrachtgevers op vernieuwende wijze inzichten en integrale adviezen bij beleid en besluitvorming, en dragen uiteindelijk bij aan een duurzamere wereld. Het LEI maakt deel uit van Wageningen UR (University \& Research centre). Daarbinnen vormt het samen met het Departement Maatschappijwetenschappen van Wageningen University en het Wageningen UR Centre for Development Innovation van de Social Sciences Group.

De missie van Wageningen UR (University \& Research centre) is 'To explore the potential of nature to improve the quality of life'. Binnen Wageningen UR bundelen 9 gespecialiseerde onderzoeksinstituten van stichting DLO en Wageningen University hun krachten om bij te dragen aan de oplossing van belangrijke vragen in het domein van gezonde voeding en leefomgeving. Met ongeveer 30 vestigingen, 6.500 medewerkers en 10.000 studenten behoort Wageningen UR wereldwijd tot de aansprekende kennisinstellingen binnen haar domein. De integrale benadering van de vraagstukken en de samenwerking tussen verschillende disciplines vormen het hart van de unieke Wageningen aanpak. 